\title{
Development Strategy for a Textile Firm
}

\author{
Luu Trong Tuan ${ }^{1}$ \\ ${ }^{1}$ University of Social Sciences and Humanities, Ho Chi Minh City, Vietnam \\ Correspondence: Luu Trong Tuan, University of Social Sciences and Humanities, Ho Chi Minh City, Vietnam. \\ E-mail: luutrongtuan@vnn.vn
}

Received: September 26, 2011 Accepted: December 10, 2011 Online Published: May 24, 2012

doi:10.5539/jms.v2n2p136 URL: http://dx.doi.org/10.5539/jms.v2n2p136

\begin{abstract}
The researched firm is a state-owned company of more than forty years of operation and is one of pioneer companies providing textile and garment to Vietnam market. Its vision is to be the sustainable multidisciplinary firm which operates in three main areas: textile and gament industry, travel - real estate and financial investment in global market. After more than forty years of operation in the market, company has obtained some recognized results but these are still low and do not meet company's strategic goals and company's shareholders expectation. A need of a development of strategy which will help company to take market positioning and to develop. This research will help to have an overview of company, its business environment, its strengths, weaknesses, opportunities and threats. Business environment and SWOT analysis are used for alternatives of strategies. Each activity of the company is reviewed to find the real problem that company is facing and helps to find a solution. A strategy is finally given for company's competitiveness anddevelopment.
\end{abstract}

Keywords: development strategy, SWOT analysis, textile industry, Vietnam

\section{Introduction}

Vietnam is expected to grow as a manufacturing base to supply to foreign buyers in developed countries. More and more orders from corporate buyers are supposed to take place. As a matter of fact, Vietnam's textile and garment industry plays an important role in the Vietnamese economy. The industry consists of around 2,000 enterprises; of which 25 are state-owned and 1,500 are private enterprises including 450 foreign-owned enterprises, with over 2 million employees involved. $55 \%$ of them are located in and around Ho Chi Minh City, $30 \%$ in and around Hanoi, and $15 \%$ in and around Da Nang. Vietnam is ranked as the 10th largest textile and apparel export country in the world.

The textile firm under research is one of the company plays leading role in the development process in Ho Chi Minh City. Established in 1965 with experience of over forty years of operation, it is developing rapidly in its business with an average growth rate $15-20 \%$ per year in terms of revenue. During the past years, it paid attention to supply textile and garment products with high quality to the customers. As a result, after Vietnam joining WTO, it has fierced competition with other rivals to gain contracts. Along with supplying textile and garment products for the domestic market, it will take part in the external market. Therefore, in next years, it must face directly the competition from domestic and foreign rivals. The question "How to keep its current customers and expand its business activities to the nationwide market?" will be answered through the findings of this research study, which helps:

1) to have a good understanding of the background of the company with its structure, performance and strategies.

2) to understand the environment of the company with external and internal analysis.

3) to understand strength and weakness that company is having, threats company is facing and the opportunities that company will benefit.

4) to understand the strategic decisions made by the company to develop in the competitive market.

\section{Literature Review}

\subsection{Strategy}

Throughout the history the term strategy reflected strong military roots. Army leaders used strategy in dealing with their opponents. Numerous military theorists (Sun Tzu, Alexander, Clausewitz, Napoleon, Stonewall 
Jackson, Douglas MacArthur, etc.) have written about strategy from many different perspectives (Pitts and Lei, 2000). More recently the term is used in a different way; nevertheless the basic idea is still the same - how to manage given resources and conditions to achieve competitive advantage over a rival. Henderson (1989) described strategy as a deliberate search for a plan of action that will develop business's competitive advantage and compound it. Another great economist Porter (1979, p.11) argues that "the essence of strategy formulation is coping with competition”.

On the contrary, Ohmae (1988) did not put the competition in the first place when making a strategy. He agrees that it should be taken into account, but should not come on the first place. In his opinion the most important thing is careful attention to the needs of customers. Before company test itself against competition, strategy should take shape in the determination to create value for customers.

One can with certainty affirm that strategy is hard. Its intellectual foundations are made from pieces of various primary disciplines including finance and economics, organizational sociology, political science, and cognitive psychology, all of which are continuously evolving at their own pace (Cheah, 2002). Furthermore, the involved people in strategy (formulation, analysis, definition, assessment, etc.) are diverse, ranging from academicians to managers and consultants acting in different industries and sectors. Apparently, this mixture of different disciplines and players ensures that consensus about "strategy definition" is almost impossible to be made.

Even though there have been numerous researches done on the field of strategic management, yet no author could identify one best strategy that would fit to all companies and would achieve equal success. Even more, there is also no single recipe to make a good strategy. According to Goold and Campbell (1987), "there is no one best way to do that. Rather, the best way always depends on the nature and needs of the businesses in the company's portfolio, on the styles of the people in the corporate office, on the company's strategy and goals".

The core of strategic management is strategic planning, i.e. the process of: setting missions, goals and objectives; clarifying policies and principles; and searching for opportunities and threats while preparing to exploit the first and avoiding the second. This process differs from one firm to another. It can be formal or informal, regular or not, depending on the business environment and the organization's strategic aims (Price, 2003).

\subsection{Business Strategy}

The main reason why company would develop a competitive business strategy is to achieve a competitive advantage over its competitors. The essence of competitive business strategy for organization is achieving a favorable match between the firm's distinctive competence and the external environment in which it competes. Therefore it is crucial for the firm to focus on different dimensions of its environment while making a business strategy. The most important of these are to discover new opportunities, to divert potential threats, to overcome current weaknesses, to sustain existing strengths, and apply strengths to new fields. Every firm has to deal with these strategic environmental factors on a continuous basis (Pitts and Lei, 2000).

Another thing that should be addressed when talking about the strategy is a distinction between business strategy and corporate strategy. Nowadays many companies, while pursuing a higher return and lower overall corporate risk, diversify their business portfolio, i.e. they are competing in different businesses. Thus, business strategy is referred as the one that ensure successful ventures of individual business unites, whereas corporate strategy concerns the operations of the entire firm.

Porter (1985a) identified three main types of generic strategies that companies can adopt as being: cost leadership, differentiation and focus. A company's relative position within an industry is given by its choice of competitive advantage, either cost leadership or differentiation, and its choice of competitive scope. Regarding the competitive scope company can target broad industry segment or focusing on a narrow segment. Generic strategies are useful because they characterize strategic positions at the simplest and the broadest level. Furthermore Porter argues that achieving competitive advantage requires a company to make a choice about the type and the scope of its competitive advantage. There are different risks inherent in each generic strategy, but if a company tries to do deliver "all things to all customers" it is a sure strategy to end up somewhere in the middle and consequently not achieving any advantage.

\subsection{Strategic Management}

The main theory which forms the foundation of strategy is the Theory of Strategic Choice. In simple terms what this theory purports is that organisations change primarily in ways that are chosen by their most powerful members (Stacey, 2000, p. 19). This theory advocates the making of such choices on the basis of a rational selection criteria and predicted outcomes. In various forms, Strategic Choice Theory currently dominates discussions of strategy and organisational dynamics amongst both practitioners and researchers. This theory is 
built on the foundations of cybernetic systems theory and takes a largely cognitivist view of human action. Cybernetic systems depend upon the possibility of prediction over a long enough time period at a fine enough level of detail, if they are to achieve the control that is their central concern. Cognitivist psychology assumes that individuals are autonomous and that they learn essentially through negative feedback loops. The theory emphasises the logical capacities of the individual and it is this that enables choices to be made. Richardson (1991) argues these are central themes that run through Strategic Choice Theory.

Strategic Choice Theory subscribes to the rational, analytic sequence of steps prescribed for the formulation of long-term strategic plans. The steps involve analysing and forecasting market development, as well as the financial and power implications of alternative action options. The result is intended to be a design to guide the development of the organisation for a reasonably long period. Furthermore, it is a template against which the actions of individual

Managers can be measured. The assumption is that if the plan has been put together skilfully enough it will go a long way to ensuring the organisation's success. However, the plan only provides the blueprint against which action is evaluated. Success requires effective implementation.

Strategic management is based on the belief that an organization should continually monitor internal and external events and trends so that timely changes can be made as necessary. An organization must be competent to astutely identify and adapt to change. The need to adapt to change leads the organization to key questions such as: what kind of business should the firm engage in? is the firm in the right field? Should the firm reshape its business? What strategies should it pursue? Other cognate questions could also be raised (Aluko, Odugbesan, Gbadamosi, and Osuagwu, 2004).

Thompson and Strickland (2003) viewed strategic management as the process whereby managers establish an organization's long-term direction, set specific performance objectives, develop strategies to attain these objectives in the light of all the relevant internal and external circumstances, and undertake to execute the chosen action plans.

According to Drucker (1974), the prime task of strategic management is thinking through the overall mission of a business, i,e. asking the question what is our business? This leads to setting of objectives development of strategy and making of today's decision for tomorrow's result. This should be done by balancing the current objectives and needs against those of the future in the light of available resource (both present and future) of men and materials.

Studies on strategic management have shown that strategic management is concerned with deciding on strategy and planning how that strategy is to be put in to effect. It can be thought of as having three elements within it: there is strategic choice stage which is to' do with formulation of possible courses of action, their evaluation and the choice between them. Finally, there is a strategic implementation stage which is to do with planning how the choice of strategy can be put into effect (Aluko et al, 2004; Kazmi, 2008).

Recent research on strategic management such as Nmadu (2007) and Akingbade (2007) have found the interconnections between the strategic management and corporate performance. For instance there studies revealed that a SMEs corporate financial performance tends to increase with a unit increase in the level of practice of strategic management. The higher the overall level of strategic management practice by a SMEs, the higher the financial performance of the SMEs expressed in terms of earnings per share, profit before tax, return on capital employed, net asset, current or working capital ratio, increase in relative market share, continuing addition of new products and products lines, and total deposits. For all the financial performance indicators used, performance tended to increase significantly as the level (or degree of sophistication) of strategic management increased.

\section{Methodology}

When deciding what research approach to use there are several options for a researcher to consider. There are two different ways of drawing research conclusions and the options consist of deductive or inductive approach. When it comes to investigation information the two different methods to choose are quantitative and/or qualitative method. To be able to provide the best and most valuable result, choosing the strategy that is most suitable for the study is very important (Jacobsen, 2002).

\subsection{Deductive or Inductive Approach}

In a deductive research approach, according to Neuman (2003) you begin with an abstract, logical relationship among concepts, and then move concrete empirical evidence. After analyzing the data you find out if the findings supported your theory and if the reality actually is what the theories earlier stated (Jacobsen, 2002). In 
contrast, Neuman (2003) state that when you use an inductive approach you start with detailed observation about the world and move towards more abstract ideas and generalizations. The researcher goes into the reality without any expectations and develops generalizations to identify relationships (Neuman, 2003). According to Jacobsen (2002), the inductive approach can lead to developing new theories. The approach used in the study is a deductive approach since the study was based on theoretical framework of references that was compared to be able to gain empirical data.

\subsection{Quantitative or Qualitative Approach}

When choosing to use a quantitative and/or qualitative approach the researcher has to consider what will be the most appropriate approach for the study since it will set a structure for the study (Jacobsen, 2002). The empirical data in a quantitative approach is expressed as numbers or charts and in contrast a qualitative approach is expressed as words, pictures or objects (Neuman, 2003). When using a quantitative approach the researcher has to collect a large amount of numerical and statistical data (Jacobsen, 2002). The information gathered must provide a result that is valid and reliable in order to be measurable (Bryman, 2002). Using a survey is a common way to collect the data, and using prearranged answers makes the result easier to measure (Jacobsen, 2002). The study used already conducted quantitative research from secondary data such as market size and sales statistics.

However, a qualitative approach is very important to use when researching the international market since the researcher often is unfamiliar with the foreign market, and by using the approach it can help determine the differences between the domestic and the foreign market (Doole and Lowe, 2004).

Qualitative research approach is an unstructured, exploratory research methodology based on small samples (Bryman, 2002). When the purpose of the study is to develop a deeper understanding of the problem and the environment around it, a qualitative research approach is appropriate to use (Neuman, 2003). The most common way to use this approach is through interviews, which will enable the researcher to get more into depth regarding the research questions (Bryman, 2002). Furthermore, the approach is flexible, and because of that the researcher has the advantage of being able to change parts where information is lacking (Jacobsen, 2002).

According to Bryman (2002), a qualitative approach is the right approach to use when looking to gain a deeper understanding of the development of peoples experience and how they react to different situations.

According to Denscombe (2000), a qualitative research approach is suitable when human activities or when behavioral patterns will be investigated. Furthermore he discusses that a qualitative research approach is distinguished due to the researcher's own interpretations and analyzing. Qualitative research leans towards an unstructured small scale carefully selected individuals approach with a purpose to gather non-quantifiable information that provides insight into a behavior, motivations and attitudes (Wilson, 2003). Based on this information, a qualitative research approach was used, since the empirical data was collected on a small scale level and since the purpose of this research was to gain a deeper understanding of actions in certain situations. The ambitions of this research was to gain an in-depth view of this situation, hence qualitative research was most suited.

\subsection{Research Strategy}

Case studies are appropriate for small scale researches that handle few units in a narrow perspective and where an in-depth study is going to be conducted (Denscombe, 2000). He further explains that a case study focuses on relations and processes to get a perspective of how these are linked together, the research is also conducted in a natural environment without control over situations, and it also provides the researcher with the opportunity to have different sources and methods. Yin (2003, p. 13) states that a case study is "an empirical inquiry that investigated a contemporary phenomenon within its real-life context, especially when the boundaries between phenomenon and context are not clearly evident." He further states that a case study answers questions that have a character of "how" and "why". A multiple-case study is suited when two or more entities are studied and compared, and the benefit of this is that it increases validity (Yin, 2003). Yin (1994) argues that within multiplecase studies there are holistic multiple-case design which is suited when the global nature of an organization is examined.

According to Stake (2005) a single case study is described to assist the collection of particular information on a single entity across a wide range of dimensions and multiple sources. A case study is a valuable method of research with distinctive characteristics that make it ideal for many types of investigations, and because of its use and reliability it is a widely used methodology (Tellis, 1997). Stake (2005) describes the case study approach as a study where you puzzle together the information collected from the environment in order to develop a general understanding. Furthermore, Ghauri and Grönhaug (2005) describe this approach to be exploratory. The aim of 
an exploratory research is to gain a better understanding of the subject and it is used in defining the threats and opportunities that may arise during the study (Kinner and Taylor, 1996). Tellis (1997), states that through exploratory research, participant-observation allows the researcher to actively participant in the events being studied and provides some unusual opportunities for collecting data. When using why and how in the research questions Yin (1994) state that the case study is the most suitable strategy to use, and therefore we found this to be the best way to investigate our purpose.

\subsection{Data collection Methods - primary and Secondary Data}

In order to collect all the information needed for a study most authors combine primary and secondary data (Yin, 1994). Secondary data is information and material collected by other people, and examples of this can be articles, books and internet (Neuman, 2003).

Primary data is when the researcher collects the data on his/her own, and go directly to the primary source (Neuman, 2003). Primary data can be collected through observations, surveys and interviews (Yin, 1994). This study used a combination of the two in order to fulfill the purpose of the study.

Secondary data was gathered through company brochures, annual reports, books, articles and the internet and then used in the literature review and the findings chapter. The purpose of this data gathering strategy is to reinforce insights and provide a deeper and clearer understanding about the firm's business strategy.. The secondary data collected enabled the researcher to receive information as regards its market share and revenue statistics, which was helpful when analysing development strategy.

After collecting the secondary data the author found that more information was needed regarding its business activities and strategies, the interview guide was then developed in order to gather the additional information needed to answer the purpose of the study. The primary data collected was then used in the findings and discussion chapter of the thesis.

In order to gather the information needed about the firm, the interview with the middle and top managers were conducted. The purpose of the interview was to find out more about the company's history, resources, competencies and strategy. The main goal with interview with managers is to find out meanings and interpretations, and to receive a deeper understanding that can be useful for the study. When conducting interview with respondent the researcher can either use a personal interview or a telephone interview (Jacobsen, 2002). The preparations before each interview should be thoroughly and well prepared. The method of documentation is important to guarantee that no information is lost. Useful tools are paper and pen or a tape recorder (Bell, 2000). The author just relies on pen and paper during the interview process. The author also tried to reflect over how respondents physically reacted to questions.

The interview guide was developed from the theories used in the literature review chapter. During the interview the researcher used the interview guide as a foundation, follow up interview questions were also asked during the time. The interviewer should constantly keep clear in mind of what information is wanted from every respondent. This implies that the formulation of the questions are of great importance and the interviewer should keep clear the purpose and goal of each question. It is also important that the interviewer can explain the terms and happenings that are questioned in the interview. Another way of clarify the purpose of the questions is to prepare certain clear examples of unnecessary misunderstandings between the respondent and the interviewer (Adermark and Britz, 2002).

\subsection{Sample Selection}

When deciding who to invite to interview the author has to think back to the purpose of the study and try to find out what people can give you the information needed (Kruger and Casey, 2000). Since the purpose of the study was to find out which strategies the firm implemented in the past years and how will they orient to their business development in the future, so the author decide to interview with twenty two middle and top managers of the firm, who know clear about the company's strategies.

\subsection{Quality Control}

When the analysis is conducted it is of outer most importance to check the quality. In a quantitative interview there is a great deal of statistics methods to use. In a qualitative investigation there are fewer methods, which makes it harder. In this case the help of reliability and validity can control the quality.

\subsection{Reliability}

Reliability is used to find out how reliable and trustworthy the research is (Jacobsen, 2002). The more consistent the results are from the frequent measurements the higher is the reliability (Johnson and Reynolds, 2004). To 
enhance the reliability of the study the researcher sent the interview to the company in advance, which gave the respondent the opportunity to get organized for the interview and in turn provide the correct answers needed.

The researcher had in mind to not influence and asking leading questions to the interviewees of the researched firm, and therefore more trustworthy information was gathered (Jacobsen, 2002). The interviews were done in Vietnamese since the mother tongue of the respondents was Vietnamese. This decreased the risk of misunderstanding during the interview, but since the interviews were translated into English the reliability may have been affected.

\subsection{Validity}

According to Johnson and Reynolds (2004), the validity involves the association between the measure and what is supposed to be measured. In this study the validity of the information is strongly dependent on the sources, since majority of the data is collected through different references. The researcher are going to be critical towards all the information. In order to know that the right sources needed for this study is used the researcher are going to be critical towards all the information collected (Jacobsen, 2002).

According to Yin (1994) there are three different tests that can be used to determine the quality of the case study, and these are construct validity, internal validity and external validity. Multiple sources should be used to enhance the construct validity, and in the study the researcher collected data through documentation and interviews. During the interviews pen and paper were used in order to take notes what was said, it also helped to make sure that no information is lost. The interview with the company the researcher made sure that the interview was conducted with the most suitable respondent, which was the middle and top managers of the company. According to Yin (1994), the external validity is dependent on if the results of a case study can be generalized or not, and since the study is a single-case study of the firm, the external validity is fairly low.

\section{Findings and Discussions}

\subsection{Overview of the Researched Firm}

The firm was established in 1965. It is a state-owned company and is one of the biggest textile companies in the industry with 7.466 workers, and over 1,000 billion VND of annual sales turnover. They produce yarns, towels, denim fabrics, garments and sewing threads of all kinds. Main garment product is basic denim jeans (cotton denim, straight denim, twill, khaki, calico) with specializations in manufacturing denim with fashion values as slub, crosshatch and jacquard. In 1988, it started a joint-venture with COATS Plt of England. It also has a modern spinning mill with the technologies of Muratec and Rieter. The company do not import fabrics, delivery time when not in stock is 15 days. The company export for 30 - $40 \%$ to Japan, $50 \%$ to US and $10 \%$ to other countries. Exporting countries in the EU are Germany, France and Belgium. It has export experience of 5 years, but they do not have experience with exporting small fashionable orders. In future the company want to expand and keep 1-2 lines for fashionable orders.

Capacity: 6 million jeans/year

Factory: spinning (3 factories), weaving (2; 1 for fabric and 1 for furry towels), finishing and dyeing (1) and make garment (2).

Located in Ho Chi Minh City, Hanoi, Danang and Nha Trang.

Customers: DKNY, Bennetton, ENYU, OKD, Saitex, Promotex, Angel Kiss.

Delivery times: garment production 30 days if fabric available; 45-60 days including fabric production; making sample 5 days; after approval it takes 10 days to start the order which takes 15-30 days to cut and sew only; shipment to The Netherlands 25 days.

Staring out with modest operation in 1965, it is now one of the most successful and biggest textile and garment company in the industry with over 166 million USD of annual sales turnover. In the last decade the company has adopted market orientation, seeking synergies, and taking new business opportunities. Leaving the outdated business concept behind, the company gradually grew into a firm offering wide range of products as today.

Being a manufacturer, it produces yarns, towels, denim fabrics, garments and sewing thread of all kinds. Facility integration enables it to offer different groups of textile with consistent quality and competitive price and be company's key strength in penetrating new markets. Today, Its customers diversely present from domestic to major international market regions such as EU, U.S, and Japan.

Partners: Its products are highly valued in quality by many garment trading firms and leading supermarkets at home such as Metro, Big C, Coop Mart, Vinatex and those abroad such as Harbor Linen, Anvil, Shigemistu, 
K-mart. One of the key consumers, American Target supermarket corporation have chosen the researched firm as one of the target partner and commited a long-term cooperation.

Operating goals:

- Trading profitably, remaining and developing the capital, completing producing-trading tasks issued by managers.

- Increasing shareholders' revenue, creating stable jobs, improving working condition gradually and raising the workers' income.

- Fullfiling the producing and trading duties following laws and sharing the social liabilities.

- Sustainable developing to become one of the leading towel suppliers in the world, having modern technology, managing ability and high specilization, strong compatibility and accessibility into global economy.

Development orientation:

- Intellectual capital is considered as the decisive factor, so the top and key tasks detemined are building. Training and fostering staff in order to help them have good managing ability, good English, undertaking many works and understanding laws...In addition, the company not only focuses on recruitment to choose the best employees, selecting and sending the officers to training units at home and abroad but also training and improving the skills of workers.

- The company also emphasizes on building legal finance and paying proper attention to researching and market studying. Then, the company plan suitable marketing policies, analyze and decide the target market which is potential in near and far future.

- Varifying lines of products, specializing production, developing general trading network, enlarging distributing channels at home and abroad. Specializing the building and developing the brandname of the company and products.

- Firmly keeping and promoting business cultural character. Making the best condition and policies in order to support workers' living and benefits.

Orders have been increasing year by year since the company was established, and sales have been impressive:

Table 1. Revenues since 2006

\begin{tabular}{cccccc}
\hline Year & 2006 & 2007 & 2008 & 2009 & 2010 \\
\hline Revenues (in billion VND) & 1,018 & 1,120 & 1,067 & 1,174 & 1,350 \\
\hline
\end{tabular}

Source: The firm's annual report, 2010

Textile and Garment is traditional production and trading of the firm. To be able to maximize value-added to customers and reach their satisfaction, it has to:

1) always improve products quality by using modern technology

2) incessantly develop plentiful and diversified products' model

3) provide the whole of textile and garment products chain: Yarn \& Thread - Towels - Fabric Garment.

\subsubsection{Strategic Posture}

The strategic posture of the company is expressed through vision, mission, strategic goals and strategies.

\section{Vision}

To be the sustainable multidisciplinary firm which operates in 3 main areas: textile \& gament industry, travel real estate and fincial investment in global market.

\section{Mission}

Improving economic potential and living-standard of the society by providing high value products and services that meet demand and maximize added-value to our customers.

The company has several strategic directions:

- Designing business plan which is guiding company's development based on turnover growth, profit and social contribution. 
- Building a professional and friendly working environment; technology application for working process building, management basing on ISO standard.

- Market expansion and increasing competitiveness by commitment to quality of product, technology and services to customers. Ensuring to meet customer's highest demand.

- Taking care and improving quality of life of employees and attracting qualified human resource from outside coming to work for company.

- Respecting legal, policy in accordance to regulation.

\subsubsection{Strategic Goals}

Strategic goal is build up based on the company development strategy which was accepted and approved by company management board. The goals include organizational structure, business development, market, growth and image of company. These strategic goals are divided into 2 periods of development which is 5 years duration.

\section{Period 1: 2010-2015}

- Building and consolidating of company's activities

- Looking for and developing, and occupying the local market.

- Turnover varies from 200 million to 500 million USD annually, with growth rate of 20\% per year.

- Building and promoting company's brand name in the market and industry.

\section{Period 2: 2015-2020}

- Developing and completing company's activities

- Enlarge export market of its services

- Turnover will be 800 million to 1 billion USD, profit 20\% with annual growth of $25 \%$.

- Achieving a stable development.

- Consolidating of brand name internationally.

\subsubsection{Business Strategies}

In order to achieve company's strategic goals, management board has set up main business strategies, identify exactly customer's demand for classification and building strategies of market entrance and occupation in each specific period based on the company's vision. In the first period of development, company's strategy is concentrated in local market by expanding their presence in main cities to gain the opportunities and serve customers with highest quality. For next step of development the company will expand its services outside of the country by export its products for oversea markets.

To keep and maintain the current customers, the company applies the following strategies:

- Build strong database of target customers in different industries and sectors. A program will be implemented to follow up and take care of customers and potentials.

- Collecting information about customer's needs and requirements regularly to understand well enough continuously to create superior value for them and create their satisfaction.

- Building stronger relationships and loyalty with key customers and customers group.

- Having better cooperation between different departments in the organization to serve customer needs.

In order to compete in the market, the company improves its competitiveness through:

- Collecting information about market and competitor's product and activities regularly.

- Conducting regular benchmarking against main competitors to respond immediately to competitor's action.

At present, human resource has been playing a key role in development of textile enterprises in general and this firm in particular. Being aware of that fact, it during the recent years has adopted the recruitment policy to ensure that the firm will attract the most highly qualified workforce available. It is our intention to make know information about employment opportunities at the firm to the largest practicable number of persons necessary to ensure compliance with the law, attraction of new employees, and recognition and development of current employees. Thanks to that policy, it has recruited engineering talent who come from the top Universities in Vietnam and skilled workers. Figure 1 shows the growth of its workforce in recent years. 


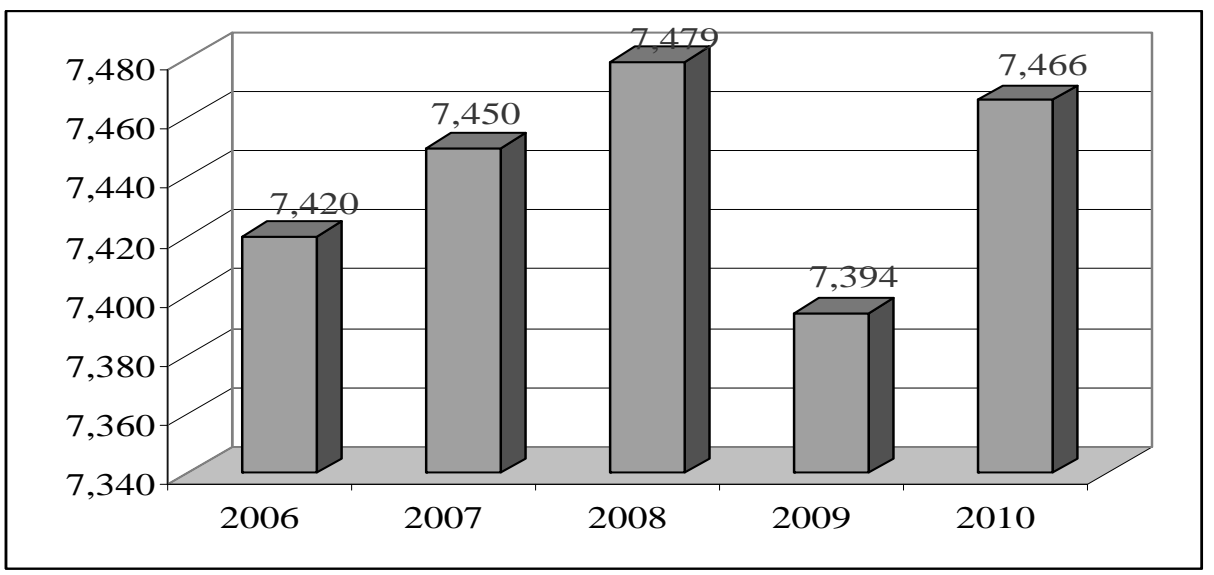

Figure 1. Growth of the firm’s workforce

\subsubsection{Industry Analysis}

This part provides analysing in competition situation and market attractiveness of textile and garment industry in Vietnam. An industry is a group of firms that market its products closely substituted from each other. According to Porter (1980), some industries tend to become more profitable and competitive than the others. Hence, an existing industry such as the firm based in Vietnam should always remember that their industry will only survive by utilizing a strategy that would enhance the competitiveness of the business. In Porter's model, it is assumed that there are five forces that particularly affect an industry. The model is useful if a manager strives to get the better off rivals. The framework provides excellent understanding of the industry context in which the firm operates.

Porter's Five Forces Model includes threat of entrance of new industries. The main objective of the firm is to stay in the competitive position in the global market Although, the company knew that this type of industry belongs to higher entry barriers, the management has been able utilize an approach to make sure that the company will still be competitive in the international level. In order for the firm to compete and stay in the international marketing environment, the management team had provided a long term vision to be followed by the industry as a whole. The use of merging and acquisitions has been able to strengthen the capability of the company to strongly and efficiently compete within the marketplace in both local and international arena.

Moreover, with the existence of new entrants in this kind of business, the competition becomes tougher and tougher. Since, these new entrants can be a threat for the company in terms of substitute products, the firm again utilizes a strategy that will enhance their product more. Product differentiation approach was implemented by the company as their marketing strategy. This is to ensure that with these new entrants their product will still be different, unique and full of quality to satisfy their target market.

\section{Barrier for new entrants to cooling tower industry}

In the textile and garment industry Vietnam, a new company wants to operate production has to face some major barriers:

- Need investment for factory and production line with complete toxic treatment system and anti-pollution standards.

- Need production technology which have to be transferred by foreign firms

- Finding foreign suppliers provide the key materials with a stable cost and quantity.

- Brand name is registered in order to protect it from imitation products.

- Need budget for marketing set up distributor net

- Facing up to strong competitors in the same market. Especially is competing with the Chinese firms, who have advantage of price.

For the new trading company in textile market, there not much entry barriers for them to set up business, but in the long term, their business will very depend on external factors such as dealer ship with supplier, product 
characteristics, fluctuation of price and of course, strong competition market will compact on the cost and benefit.

Bargaining power between buyers and the company

Now in Vietnam textile and garment market, the requirement estimated is: fiber 400,000 tons; fabric 1,000mil meters; towel 70,000 tons; garment 3,500mil units in year 2011 while the quantity of textile and garment import into Vietnam is rising up and possible fill the market needs. Therefore, customer has high bargaining power.

In the firm, the production process also very depends on raw material's suppliers, this leads it less bargaining power in its procurement process.

\section{Bargaining power between suppliers and the company}

In textile and garment manufacturers in Vietnam, as the local materials needed for composite covers are could not meet quality requirements as well as quantity, therefore most raw materials are imported from China, India, Korea and Pakistan's supplier. Those material take $30 \%$ of production cost, because of this, any changing on material cost or interruption of supplying will be strong impacted on product's price as well as production planning.

Raw materials for composite production such as cotton, yarn, glue, chemical liquid and additional are very difficult to stock for long time, they need to be ordered frequently as production planning.

\section{Competition amongst the existing companies}

The textile and garment manufacturing segment in Vietnam is made out of numerous manufacturers which almost are varied in terms of size and power. It is a massive sector with thousands of companies producing apparel. Hence, the rivalry between apparel manufacturers is diverse since they enjoy different growth rates. Additionally, textile and garment as a perishable product group is in the risk of temptations to cut prices when demand slackens. For example, when there are recessions in the business cycle apparel prices will drop significantly in price. Both these factors exemplify and indicate that the rivalry between manufacturers is high. As Vietnam apparel manufacturers are pressured to lower prices in order to stay competitive with companies abroad, the overall rivalry within the industry gets companies to expand their customer base in order to keep profits up. It is therefore reasonable to believe that such expansions may occur on the behalf of competitors if possible, and thereby increase the rivalry in the industry. The market shares of the textile and garment industry is presented in Table 2.

Table 2. Textile and garment's market share (\%) in Vietnam

\begin{tabular}{llll}
\hline Firms & Year 2008 & Year 2009 & Growth \\
\hline The researched firm & 31 & 33 & 6.5 \\
Viet Thang & 28 & 29.5 & 5.4 \\
Thai Tuan & 16 & 17 & 6.3 \\
Others & 25 & 20.5 & -18 \\
Total industry & 100 & 100 & \\
\hline
\end{tabular}

\section{Threat of substitute products affecting the industry}

When using such as broad term as Textile, there are obvious reasons for identifying substitute product groups proves difficult.Of course, there are variations in types of clothing and material. Variations in textile segment can also be identified as trends in fashion and styles. Hence, products within the apparel segment can act as substitutes but the general conclusion still stands; there's no substitute to apparel. Porter's Five Forces model applied to the firm is showed in the figure 2. 


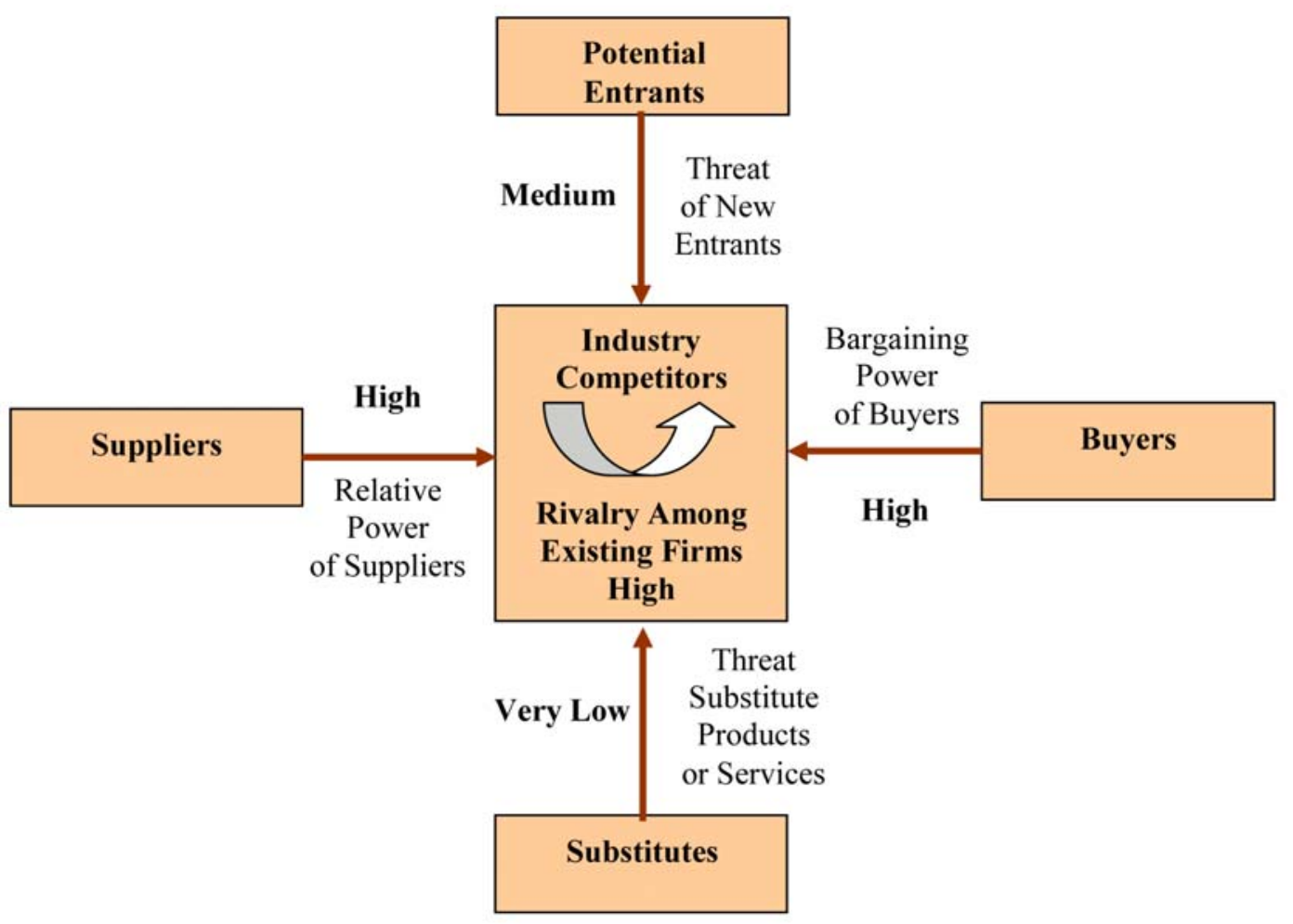

Figure 2. Porter’s Five Forces model applied to the firm

\subsection{SWOT Analysis}

\subsubsection{External Environment Analysis}

In order to set up the development strategy of an textile and garment firm, it is necessary to scan background conditions. By using PEST model, the first section of this chapter wills briefly analysis the current macro environment factors that have much impact on textile and garment market in Vietnam.

\section{Political environment}

Vietnam is now recognized as having one of the most security and stability political regime in the world. The country is almost without terror and ethnic group conflict. Therefore, foreigners are always secured when they visit or do business here. As regards international relationship, Vietnam has approved Bilateral Trade Agreement with US and officially become the member of the World Trade Organization since 2007. Within a year after joining WTO, Vietnam has attracted more than $\$ 98$ billion in foreign investments and ranked sixth in the world in attracting foreign investment. Especially, the country also has chummy and friendly relationship with a number of countries such as Japan, EU, USA which having large demands on textile and garment outsourcing service. The government always stimulates and supports foreign companies' invested and co-operate with textile and garment Vietnam enterprise in the fields.

Vietnam Government has improved their international position by expanding foreign relations and alignments with strong economy like the US and Europe and especially with Asia neighbors who are now leading FDI investors to the country.

Facing to world economic slowdown and inflation, Vietnam's Government has some immediate decisions to overcome the difficulties such as:

- The calls for extended price controls from National Assembly lawmakers have put the government's commitment to further market reforms under the spotlight, and its conduct will be scrutinized by investors.

- Growth should remain high, as the manufacturing sector expands and public investment in infrastructure continues. Meanwhile, the government's attempts to bring inflation back under control in 2011 will include increased exchange-rate flexibility, as the path of current monetary policy has proved to be problematic to 
macroeconomic stability.

- Competitiveness of Vietnam's business operating environment in supporting corporate growth and profitability over the 5-years forecast horizon is more intense as compared with regional neighbors.

These above solutions will help customers to boost their payment capabilities and overcome financial difficulties to proceed on tentative orders with sales and marketing of the researched firm. Or they will consider the ability for technology investment when they see the Vietnam Government's commitment with strong measures.

Meanwhile, the threats are still existing when foreign investors still under-estimate Vietnam policy makers for strategic policy. Tax policy is one of examples when is not really stable which not only disappointed local consumers but also foreign investors. This one of barriers to discourage to invest to the country.

External shocks by instable of neighborhood country like Thailand or relationship with China is not really good recently also make bad impacts to investment environment.

Beside, the corruption is still a barrier for business environment that frustrate local and foreign investors especially western investors. Corruption decreases business competitiveness not only of customers but also for the firm's sale and marketing activities. The firm operates in the gateway between foreign suppliers and customers in Vietnam. The corruption is always difficulty in communication with oversea suppliers and even with local investors for clarification. That's a barrier to achieve a successful deal.

\section{Economic environment}

Vietnam economy is growing rapidly in recent years (see Table 3). The economy reforms are also recognized by international community. Vietnam joined the World Trade Organization (WTO) in 2007. It is an important step for its trading development.

Table 3. Vietnam economy growth (\%)

\begin{tabular}{lllll}
\hline GDP & 2007 & 2008 & 2009 & 2010 \\
\hline China & 14 & 10 & 9 & 10 \\
Vietnam & 8 & 6 & 5 & 7 \\
India & 10 & 5 & 9 & 10 \\
Singapore & 9 & 1 & -1 & 14 \\
Thailand & 5 & 2 & -2 & 8 \\
\hline
\end{tabular}

Source: World dataBank, 2010

A favorable investment environment has attracted many foreign investors coming to Vietnam with a FDI of more than USD80 billion with 8,500 projects from 86 countries. In 2007, FDI inflow is USD 6.7 billion that contributing to $9 \%$ of GDP which continues to remain over $8 \%$ in next five years forecast. The total trade is USD 110 billion, in which export represents USD 50 billion or 65\% to GDP. The export growth is $20 \%$ over the past 20 years that ranked Vietnam as the second most externally oriented among 10 ASEAN economies in 2007 (see Table 4)

Table 4. FDI in Vietnam from 2005- 2009 (US Bil)

\begin{tabular}{lllll}
\hline 2005 & 2006 & 2007 & 2008 & 2009 \\
\hline 1.9 & 2.4 & 6.7 & 9.5 & 7.6 \\
$4 \%$ of GDP & $4 \%$ & $9 \%$ & $11 \%$ & $8 \%$ of GDP \\
\hline
\end{tabular}

Source: World dataBank, 2010

The economic environment created some opportunities for sales and marketing of the researched firm as there are a variety of customers' sources because:

- More foreign customers will come to invest in Vietnam. They will invest in technology and equipment for manufacturing and R\&D. There are more orders coming from these customers who already known the 
technology and are strong in term of financing capability.

- In order to increase competitiveness to foreign companies, local companies have to invest in technology and R\&D. The potentials now include local companies who were not its customer's target before.

- Local mechanical companies have been weak for years by lacking of orders will now have also more opportunities for outsourcing and exportation to Vietnam's manufacturing that include manufacturers, mold and die companies.

\section{Social environment}

Vietnamese people are easy to be assessed, hardworking, intelligent, and quickly to catch up with new trends. Workforce is young, interested in learning. They are confident and have more chances to find employment. Human resource has more competitive advantage comparing to other countries. All of these are one of the most considerations of investor to consider before they make investment.

Formerly, Vietnamese had the habit to live in countryside. More than $80 \%$ of the population lived by agriculture. However, the thing has been changed for the appearing of industrialization and urbanization. Most of them go to big city and industrial zone to find job. People leave their family for employment. This trend offers large human resource for the textile and garment companies, manufacturers. Nevertheless, on an opposite side there are problems created along to this residence movement such as lack of labor in rural area, new accommodation, securities, health, environment, infrastructures and so on.

As a developing country, Vietnamese is geared with dynamic, holding an inquiring mind people. They are great human resource for all investor to start out a business. However, the company should exam careful the characteristics of their employee to provide suitable support and to ensure their employees are not the reason of new social issues.

\section{Technological environment}

Vietnam is still not considered as an industrial country. Technology in manufacturing is still low level in both technology and equipment. This could have been a good opportunity for sale and marketing of the researched firm when they see potentials orders there for improving manufacturing ability by investment in technology and equipment. But there're still other reasons like weak financial capability or human resource. Local companies are not considering to changes especially in new technology. They feel unfavorable with it by weakness in technological level. Even when new technology or equipment installed, they faced to application and operation because their engineers are not good in their performance. This is due to educational system.

Because of low R\&D level, almost of textile and garment companies don’t focus on R\&D, they are happy with outsourcing for foreign customers with simple technical requests. So investment in technology and equipments is not their consideration either priority.

The government commits to continue to pursue its aim to gradually modernize and turn Vietnam into an industrialized country by 2020 which is one of key strategies Vietnam aims to achieve. To implement this strategy, Vietnam government will invest much into technology. Next to education, advanced technology and equipment will be invested. These two sectors are actually the main products and market the researched firm is focusing on.

\subsubsection{Internal Environment}

Analyzing the internal environment of the researched firm is to help it to find out the strengths and weaknesses to be overcome.

\section{Human resources}

Along with investments for production investment, human resource training is a problem which needs attention of the managers. Why do we have to train? In its relation with personnel policy and, in a broader sense, with the company's business and development strategies, training is an essential factor and an important step in the process of human resource development for the company. Thus, training must be considered an required task, not an optional or for-fun task.

The company pays salary and reward for staffs mainly basing on the regulation of the state and its mother company instead of following the labor market. Besides, the annually training plans are not in alignment with the actual need; job description is not clear. These are difficult to motivate and retain its workforce. Nevertheless, they have not many conditions to put these trained entrepreneurial knowledge in practice as well as promote their ability because of current administrative based-model. The trainings could not make good the shortage of 
entrepreneurial skills and experience due to the educational system focus strongly on theoretical and the non-practical management environment. For this reason, there have been inevitable weaknesses and shortcomings encountered in their business direction and management. In case of detecting those weaknesses and shortcomings, the board of management could not easily and promptly find out the best solutions.

1) After defining training objectives, the firm has immediately worked out plans to hold training programs in the coming time, such as follows:

2) To enhance the capacity of the staffs of the Sales Department, concerning negotiation and contract-signing skills.

3) Recruit persons of good marketing skills for the development of the distribution system and market expansion; increase the domestic market share to $15 \%$ of the total turnover.

4) Promote the work of fashion designing, product pattern and styles by recruitment

5) Send experts and other staffs abroad for investigations and learning experiences, in such countries as Japan, Britain, the USA and Malaysia...

6) Cooperate with customers having advanced technologies, for example Mitsubishi, Marubeni,... and create conditions for the company's staffs to take part in technological transfer training courses.

\section{Finance}

As a member of VINATEX, the researched firm is supported by one of the strongest economic groups of Vietnam. In 2009, according to the firm's profile, its total assets were nearly VND 1,962 billion.

In the actual slowdown economic situation and inflation, these difficulties become more critical. Lacking finance is one barrier for building a long-term financial strategy in the researched firm. It does not have a strategy on this and not proactive in some activities.

There're two main resources of mobilization of finance. The first comes from members of management board with their financial contribution but this source is never enough for company's operation and development. This is just an initial investment. The other source comes from banking loans but high interest rate at this time always has difficulties to approach the bank for the loan. Because it will push product price go up, and the company will meet with many difficulties in competition.

Financial resource limitation decrease company's competitive capability when they have difficulties in:

- Financing for company’s business and marketing plan and their activities. Plans were built but these lack of finance for implementation. This decreases competitiveness on the product and company's image promotion, sale and marketing activities...

- Disadvantages in trading negotiations for payment terms. The firm needs finance for both up front payment to oversea supplier and local customers. They only receive full payment upon warranty is expired normally twelve months later. So they also need finance to cover all this period. This is company's weakness in comparison with foreign competitors who are strong in finance.

\section{Marketing}

Since the researched firm has not get famous brand products, it should attempt to build images, affirm the position in the domestic market, to prove to foreign partners production capacity, exports, is their first choice when they looking for partner to place orders textiles and garments in Vietnam. In order to achieve these objectives, it needs to implement:

- Expand the advertising, promotion products of the company on trade magazine, telephone directory (Yellow Pages), books for specialized research as well as company. The contents of advertisements to highlight the advantages of production capacity, international standards, which the company has achieved.

- Step up participation in textile and garment fairs and exhibitions in domestic market to promote the image of company and products to potential partners is involved.

- Build company's image to associate with responsibility for the community by participating in programs and activities such as charity, assisting the poor, the disabled and support for flood ....

- Building a system of quality standards consistent with international standards: ISO 9002, SA 8000, ISO $14001 \ldots$

Besides, its products are too specific and not so diversified. Resulted from the traditional characters of the textile and garment sector, these products focus mainly on the specific subjects and haven't satisfied various demands 
of external customers. To commercialize these particular products to outside market, the company will have to spend more time and resource on adjusting as well as design, updating them.

\subsection{Competitive Benchmarks}

Vietnam is known to have an impressive and quickly developing textile and garment industry and low labor costs. These factors make it a possible interesting and attractive market for foreign companies with strongly finance invest to. Therefore, competition more and more fierce to domestic textile and garment companies in general and the researched firm in particular. Moreover, economic crisis and inflation still affect through the country also inhibit growth rate of the firm, but the firm has their own strengths and they are confident on that because:

- They are the leading Vietnamese company operating in textile and garment. After more than forty years of working in this market, sale and marketing department have created a brand name as first local company who provide the quality products to textile and fashion design sector.

- The technology that the company has is one of leading technology with high quality that able to meet customer's demand on high technical requirement. This is used and accepted by big names in the industry like DKNY, Bennetton, OKD.

- They have a qualified human resource: Sale team combines qualified people who are well educated from leading education institute oversea and in Vietnam. They have experiences and relationship in the industry for years. With new technology, they also sent abroad for training both in technical and sale activities. The training is guaranteed by multi national companies.

However, the company still has the following weaknesses:

- Price of raw material, especially fiber, accessories tends to increase, the company can not predict the trend of the market to purchase raw materials, temporary storage of input materials for production, so do not dare to take the export contracts. This impacts significantly on the business performance of company. To remedy the situation, the company tried their best actively promoting the export of goods to oversea markets in order to balance foreign exchange for importing raw materials and increase production capacity. In addition, the company is also trying to negotiate with customers to enhance export product price.

- The sale and marketing team has also difficulties in sale negotiation on the payment terms that sometimes create the disadvantages to customers. Competitors with stronger financial capabilities will take the lead in those cases.

\subsection{SWOT Matrix}

Basing on analysis and looking at SWOT matrix, company's management board find that they have strengths and weaknesses internally and also have opportunities and threats coming from externally. The main strengths, weaknesses, opportunities and threats that company have and faced are as follows: 


\begin{tabular}{lll}
\hline & Strengths & Weaknesses \\
& - The revenue is increasing. & - Processing is mainly. \\
& - Apply technology in production to & - No famous brand name. \\
& reduce wastage of materials. & - Difficult in financial credit and loan \\
& - The labour force is abundant, hard. because of high interest rate.
\end{tabular}

\section{Strengths}

- The revenue is increasing. The firm is the leading company in textile and garment, provide high quality textile and garment products which appreciated by customers and partners in foreign market. This is a competitive advantage that they have to maintain and develop. "Since joining the WTO, export of garment products has brought no small source of foreign currency for the company. Specifically, it has increased exports of 2008 to over 17 million USD, more than 2.2 times of 2004 and accounted for $25 \%$ of total revenue of the company. This growth continues to be maintained in 2010 with export turnover U.S. \$ 24.7 million, up $20.3 \%$ over the same period last year. In the United States is the largest export market of the company, accounting for $57 \%$ of export market share, far exceeding the potential market is the EU accounted for another 18\%, Japan 9\%” said Mr. Pham Xuan Trinh - Managing Director of the firm.

- Apply technology in production. The firm owns a wide range of products that vary in terms of technologies difference with different ranges of price. That meets various of customers' segments for different applications even most technical demanding to regular one. Almost of brands are supplied by leading manufacturers in the industry.

- The labour force is abundant, hard. Company's management board usually have attractive policies to workers and qualified people such as: allowance, assistant accommodation, bonus. 


\section{Weaknesses}

- Processing is mainly. This is common situation of Vietnam textile and garment companies, and the firm also. The company still does not pay attention to create their own separate brand name, just follow available requirements of foreign companies.

- No famous brand name, the firm is weak in design, lack of professional design team so customers' awareness regarding company's name and products is low.

- Although the firm is a large company but due to inflation the company also meets difficulty in financial credit and loan with high interest rate. Company lacks of strong financial resource for improving its performance.

\section{Opportunities}

- Chance for enlarging domestic textile and garment and expand export market. The local market will be expanded and developed rapidly with participation of foreign companies; if local manufacturers and companies don't want to fail they have to invest in technology to increase their competitiveness. This trend is starting to appear, and ensure an opportunity for the firm.

- Will receive tax incentive after Vietnam joined WTO.

- Strongly supported by Vinatex and Government. With favorable policy to investment environment that Vietnam Government has been creating, Vietnam is becoming a hot destination of foreign investors. There're more flows of FDI coming to Vietnam in next years, and there're a flows of investors coming to invest and operate in country. The market will become more potential with fast and large expansion and development.

"In order to achieve 28 million USD in export turnover in 2011, the company should determine the appropriate business strategy to minimize adverse impacts and to fully exploit the competitive advantages. The company will build the strategic development, strengthen international cooperation and commercial promotion activities to promote the wider, develop separate label products of the company on international market” - said Mr. Nguyen Van Nhiem, Sales Import Export Manager.

\section{Threats}

- Slowdown economy and inflation. Parallel to opportunities that the researched firm may have, there're threats that firm may face like the economy has slowdown signs. That has started from the biggest market US and will be effect to other countries especially to developing countries like Vietnam. Vietnam, in fact, is facing to inflation and slowdown of other economic indications.

- Importing countries usually have strict requirements for quality. In order to protect local production, import countries imposed standards on products such as: non-toxic, safety, good quality.

- More intensive competition, especially Chinese competitor (government reduce import tax as WTO regulation) More flows of investment with potentials foreign customers will appear, there's a threat when there're more foreign competitors will jump into the market. Competition will become more cruel for the firm.

As Mr. Nguyen Van Nhiem said "Currently, the firm is facing great challenges. Due to fierce competition with foreign products and import tariffs. Initially, the firm is influenced by many factors, but primarily from the financial crisis, recession in major markets, competitive pressure come from Vietnam officially opened retail market to foreign companies, and due to textile and garment monitoring mechanisms of the United States, while we are not aware of all the challenges, competitive pressures in integration, leading to the lack of preparation, lack of plans for the business and difficulties in production."

- Almost raw material source depend on oversea supplier, which make firm do not hold the initiative in production.

\subsection{Alternative Strategies}

Four sets of strategies firm's management board considers after analyzing of strength, weaknesses, opportunities and threats and matching each other are:

- Strengths with opportunities: Human resource strategy will be considered to develop to host the flows of foreign investors jumping in the market. The firm has to prepares its human resources to handle more activities. The firm has already a qualified human resource but in order to meet firm's development and market expansion, this resource must be developed, trained to be more skilled and competent to be competitive.

- Weaknesses and opportunities: Not only preparation of human resource, firm needs to have strong financial resource for its operation and development to meet developing market's demand. A clear financial strategy must 
be built by the firm.

- Strengths and threats: Facing slowdown economy and threat of more competitors, existing competent sales team needs to increase and improve their technology to find more customers and take care existing ones in order to increase sale volume and attractive model if they don't want to be fail. Management board of firm has to develop a strong sales strategy for more competitiveness.

- Weaknesses and threats: One of the main problem of firm's weak performance is marketing. The firm is unaware by customers by lacking of information. Products that firm provides are well known in local market but foreign customers are unaware of its presence. All are due to weak marketing activities of the firm. So, they really needs a marketing strategy at the moment to introduce the firm and products and to attract customers' awareness. This is now a key and critical requirement of the firm's existence and development.

Four sets of strategies are explained with details are following:

\subsubsection{Human Resource Strategy}

\section{Recruitment}

In order to take the opportunity of an expansion of the market following by flows of FDI to Vietnam, the firm has to prepare its strategy of human resource especially personnel in sales and marketing department. Strategy starts by recruitment new proficient staffs for marketing division to improve marketing activities of the firm. More recruitment is also necessary to increase sales activities. Only qualified people is recruited, so that they can start working immediately with high performance but the firm won't have to spend much money on training and waste time for its market positioning.

\section{Salary and compensation policy}

Parallel to recruitment, the firm will build a salary and compensation policy to encourage its employees. A competitive salary will be offered to employees not to encouraging existing employees but to attract qualified people coming to work for the firm. Salary increasing for competent staff will be reviewed in periods like every six months and annually. The increasing scale of salary will be 10 to 15 percent in comparison with other companies working in equipment and technology trading. Incentive and compensation will be built basing on employees' performance. An instant bonus will be delivered to salesmen right after they get a contract. And a year end bonus will also delivered to them basing on annual sale performance they hit. In order to ensure a fair and encouraging of compensation, a qualification system will be built and set up for the purposes.

\section{Training}

For a firm operating in textile and garment market, training is necessary for employees to adapt new technology and its changes. The firm plans to send their employees for oversea training organized by its suppliers. These training courses are often organized to help employees update new products and its technical improvement changes for competitiveness. Next to technical training, the firm will send staffs to participate in one or two soft skills training courses on sales and marketing skills to improve staffs' skills which will help them to perform their job effectively. The training is not only planned for staffs but also for management board to help them in the firm's strategic management. In order to have best training benefit, the firm will have its qualification system for existing and new employment to qualify employees and needs of training. The firm then compares with the firm's strategic goals and objectives to have suitable training courses for best results.

\section{Working environment}

Most employees want to have a favorable working environment, so the firm will plan to create a professional working environment where employees feel happy and have friendly relationship between colleagues and even with management board. A clear regulation and tasks will be created within the firm to help them understand their job and support each others. Teamwork will be highly appreciated in the firm. Cultural values are welcome where management board respect employees' initiatives and recognize employees contribution. This is also encourage employees to share their concerns, problems and contribution to the firm's development. Team building events will be held regularly to connect people and other competitions also will be held to qualify and recognize and encourage the performance between employees. Other building activities will be taken to get staff close and reduce working stress periodically. Some activities should have staff family involved on the special occasion.

\subsubsection{Marketing Strategy}

Marketing strategy will focus on three main groups of activities which are direct marketing, advertising and event. In first group of activities, the firm will concentrate to improve direct marketing activities like design and 
getting printed the firm and product catalogue, preparing and sending direct mail basing on a strong database to potentials customers and calling for arrange meeting and following up. Group two combine advertising activities which are published in three channels of industrial magazine, online via the firm's website or others industrial websites. In addition, the firm will participate in industrial fair and exhibition and organize themselves product seminars.

\section{Direct Marketing}

- Database: Current database of the firm will be developed with new recruitments from trade shows, direct meeting and online registration and other. Update and qualification of the database will support for next marketing actions like mailing, calling. The effectiveness of these activities will depend a lot in the quality of the database. Quantity will be increased to cover target customers in the market working in different sectors like industrial, education, art, an in different segments like foreign companies and local companies.

- Catalogue: The firm and product's catalogue have to be redesigned in both languages English and Vietnamese to reach both foreign and local customers for their good understanding marketing message, features and benefits of product and service. The format of product catalogue will base on the original format of manufacturer and supplier to have international standard and image, so customer will recognize it easily and attracted.

- Mailing: Mailing activities will be increased in next period in term of quantity of customers and sending frequency. Mailing this time will not send before direct meeting and product demonstration but even after sale for taking care of customers. Every quarter customers will receive at least one mailing for products and service presentation, technology update, events or other industrial activities news.

- Calling: Sale and marketing team will not only make a phone call to customers for meeting arranging or product demonstration but also participate in recruitment of new database. Calling is regular activities of the team which is held everyday with high frequency of calling to reach maximum target customers.

\section{Advertising and $P R$}

There're two types of advertising that the firm will use are printed and online magazines.

- Magazine: Advertising pages in printed industrial fashion magazines will help to gain customer's awareness regarding the firm's products.

- Online: The firm will have to invest in their website to approach their customers.

This is an image of the firm. This is an useful and efficient way to link with their suppliers and customers. A Forrester Research shows that $43 \%$ of internet users are for research product purchases. People who interest in product may search and reach manufacturers website to research on the products and to place an order. If the firm doesn't have their good website, they will lose the opportunity to sell their products. Together with direct calling, website will support to present the firm image and product to customers beside mailing activities. This type of advertising is less expensive than printed magazine and can reach a bigger number of readers with longer appearance.

\subsubsection{Sales Strategy}

Sale activities are not currently problem of the firm, but for a competitive positioning in the market, the firm has to review and rebuild sales strategy basing on current sales activities.

By reviewing the firm's strategic goals with specific targets, the actual situation of the firm with sales and marketing activities and market trends, management board and sales team need to rebuild sales target which is in accordance with real situation for each period of development.

Sales team has to keep contact with current customers and develop new relationship by looking for new prospects. The team has to plan to follow up potentials and has a strategy to take care of those.

By visiting customers for product demonstration and taking care, sales team will collect their feedback and comment regarding the firm's products and market information especially information relating to competitors. Information of product competitors are supplying, sales channels they promote, prices they are offering and other marketing and promotions they are implementing will help marketing department for market analysis. From these analysis, the firm will have suitable actions for competitiveness.

Commission policy for customers will be reviewed which will not only encourage customers supports but also contribute in their decision making. In addition, a commission will make the firm offering price become more competitive. A clear commission policy must be built that also helps sales team for quick and flexible action to take advantage in comparison with competitors. 
Next to commission policy building, the firm will consider salary and compensation policy to salesmen to encourage them for higher performance. This salary policy has already mentioned in human resource strategy.

\subsubsection{Financial Strategy}

In order to ensure enough financial resource for the firm's operation and trading transaction, the firm has to forecast their expenses for a such period of time in at least six months or annually. Financial plan will be built basing on the firm's strategies, strategy of human resource, strategy of marketing or on sales activities with specific targets. A plan will help the firm for financial preparation and avoid to be in bad financial situation.

The firm will review their expenses and cost to avoid wastes and increase benefit for a better financial performance report. Which is important to negotiate with bankers for loan and credits terms. With a clear and feasible financial report together with reasonable expenses and cost for best benefit, the firm will have a good financial report to banks acceptance for a credit in near future.

Parallel with credit granted from the banks, the firm will mobilize other financial resources from internal and external. "For internal, the firm's shareholders will consider to increase their contributions to the firm's capital by at least $50 \%$ of actual registered capital which will support for the firm's strategic activities in next five year. This resource may come from deduction from shares that shareholders receive at the end of fiscal year.”, Mr. Tran Quang Nghi said. Other source also come from contribution of new members who want to join the firm as a shareholder. For external resource, the firm will have to negotiate with their suppliers for a long-term credit for sales by extending the payment terms and decrease the percentage of deposit. The firm will not only look for credit from suppliers but they will try to negotiate with customers to get more deposit for at least 50-60 percent from the actual rate of 20-30 percent. With two key resources from suppliers and customers, the firm will benefit much financial resources and resolve financial problem to help the firm to become more competitive.

Moreover, "reduce costs to create competitive advantage - the shortest way to improve efficiency in the investment that any business will have to take "- Technology Investment Manager Phan Kim Hang said and gave out the statistics in the three years of implementing cost reduction strategies through management solutions, equipment and technology. Accordingly, only decrease power and fuel consumption down to $5 \%$ has benefited more than 3 billion VND. Similarly, with more than 100 science and technology initiatives are implemented at the production stage in the firm, the value of the benefit calculated was close to 10 billion VND.

\section{Conclusion: Strategic Choice}

By considering four strategies that the firm want to implement to meet future development, the firm found that there're two strategies that are not really urgent at the moment as sales and financial strategies.

Finance is important but the firm is still able to resource and may rely on other source. For first steps, they can call up shareholders contribution. So, the strategy may be implemented after other strategies with long-term execution.

Sale activities are executed quite well because the team is qualified people who are members of management board and salesmen. They are not strong in background but also in sales experiences for more than ten years. The real problem for sales team is that they still lack of lead sources to exploit. With current status of sales team, they can improve activities when the firm has separate marketing team and they can concentrate on sales only. So, they can have more time to look for new prospects, follow up and take care of current customers.

After analysis of external and internal, the firm recognize that its most weakness is marketing activities and the threat of more big competitors will jump into the potential market demand the firm's management board for a marketing strategy. This is key strategy at the moment to implement before financial, sales and human resource strategies. Anyway, to implement marketing activities, the firm will use a part of human resource strategy when they will recruit marketing people for a separate marketing department. Once completed marketing strategy, the firm will start other strategies. They will need more resources for execution, more financial resource to finance the operation.

And at that time, more employment will be recruited for sales department to increase their activities mentioned in sales strategies. More training will be held to improve employees' skills and management competence. Salary policy will also be review to encourage employees. Some activities in human resource strategy will be implemented parallel with marketing strategy.

Finally, the firm's management board agrees that marketing is the critical strategy now for the firm and decides to choose marketing strategy to start first. There's a combination of marketing and human resource strategy in this case. As Mrs. Pham Minh Huong - Vice Director of the firm said: "First, building strong brand name to 
confirm the firm's position on the domestic market and gradually dominate the world market, parallel that solve the labor problem, especially in human resources with high quality in management, technology, fashion design. Enlarge cooperation with foreign partners, taking care to improve life for workers. Reduce costs to maintain competitiveness and attract orders. Next, search for domestic sources of raw materials to reduce cost and reduce the rate of processing. The state should indirectly assist in the training of workers, managers, support policy in developing areas of materials production, reduce import tax of cotton fiber. To combat the import monitoring mechanism and anti-dumping of the United States, need to have close cooperation between state agencies, enterprises and associations of importers, retailers, as well as partners from the United States. Thus, Vietnamese textile and garment enterprises in general and the firm in particular have a foothold on the world market, not only enterprises operating in the textile industry but the State also have a lot of effort to overcome the difficulties."

\section{References}

Adermark, C., \& Britz, J. (2002). Värdering av kunskapshantering. Linköping University, Linköping.

Akingbade, W. A. (2007). Impact of Strategic Management on Corporate Performance in Selected Indigenous Small \& Medium Scale Enterprises in Lagos Metropolis. Unpublished M.Sc.Thesis, Department of Business Administration \& Management Technology; Lagos State University, Ojo; Lagos.

Aluko, M., Odugbesan, O., Gbadamosi, G., \& Osuagwu, L. (2004). Business Policy and Strategy (3rd ed.). Nigeria: Longman.

Bell,J. (2000). Introduktiontill forskningsmetodik. Studentlitteratur, Lund.

Bryman, A. (2002). Samhällsvetenskapliga metoder. Liber Ekonomi, Malmö.

Cheah, Y. J. (2002). Fundamental analysis and conceptual model for corporate strategy in global engineering and construction markets. Ph.D. Thesis, Department of Civil and Environment Engineering, Massachusetts Institute of Technology.

Denscombe, M. (2000). Forskningshandboken för småskaliga forskningsprojekt inom samhällsvetenskaperna. Lund: Studentlitteratur.

Doole, I., \& Lowe, R. (2004). International Marketing Strategy: Analysis, Development and Implementation (4th ed.). Thomas Learning.

Drucker, P. F. (1974). Management Tasks, Responsibilities and Practices. New York: Harper and row.

Gharui, P., \& Grönhaug, K. (2005). Research Methods in Business Studies: a Practical Guide (3rd ed.). Prentice Hall, England.

Goold, M., \& Campbell, A. (1987). Many best ways to make strategy. In Montgomery, C. A., \& Porter, M. E. (Eds.), Strategy: Seeking and securing competitive advantage (1991, pp. 333-345). Boston: Harvard Business School Press.

Henderson, B. D. (1989). The origin of strategy. In Montgomery, C. A., \& Porter, M. E. (Eds.), Strategy: Seeking and securing competitive advantage (1991, pp. 3-9). Boston: Harvard Business School Press.

Jacobsen, D. I. (2002). Vad, hur och värför? Høyskoleforlaget AS - Norwegian Academic Press, Kristiansand.

Johnson, J., \& Reynolds, H. T. (2004). Political Science Research Methods (5th ed.). CQ Press, Washington D.C.

Kazmi, A. (2008). Strategic Management and Business Policy (3rd ed). New Delhi: McGraw-Hill Companies.

Kinner, T. C., \& Taylor, J. R., (1996). Marketing Research - An Applied Approach (Int. ed.). New York: Mc Graw-Hill.

Krueger, R., \&Casey, M. (2000). Focus Groups - a practical guide for applied research (3rd ed.). Sage Publications, London, England.

Neuman, W. (2003). Social Research Methods-Qualitative and Quantitative Approaches (5th ed.). Pearson Education Inc, United States.

Nmadu, T. M. (2007). Strategic Management in some Nigerian Businesses: “A business reality”. Journal of Management Research and Development, 1, 17-23.

Ohmae, K. (1988). Getting back to strategy. In Montgomery, C. A., \& Porter, M. E. (Eds.), Strategy: Seeking and securing competitive advantage (1991, pp. 61-74). Boston: Harvard Business School Press. 
Pitts, R. A., \& Lei, D. (2000). Strategic management: Building and sustaining competitive advantage. Ohio: South-Western College Publishing.

Porter, M. E. (1979). How competitive forces shape strategy. In Montgomery, C. A., \& Porter, M. E. (Eds.), Strategy: Seeking and securing competitive advantage (1991, pp.11-25). Boston: Harvard Business School Press.

Porter, M. E. (1980). Competitive Strategy. New York: Free Press.

Porter, M. E. (1985a). Competitive advantage. New York: Free Press.

Price, A. D. F. (2003). The strategy process within large construction organizations. Engineering, Construction and Architectural Management, 10(4), 283-296. http://dx.doi.org/10.1108/09699980310489997

Richardson, G. P. (1991). Feedback Thought in Social Science and Systems Theory. Philadelphia: University of Pennsylvania Press.

Stacey, R. (2000). Strategic Management and Organizational Dynamics. London: FT.

Stake, R. E. (2005). The Art of Case Study Research. Thousand Oaks: SAGE Publications.

Tellis, W. (1997). Introduction to case study. The Qualitative Report, 3(2).

Thompson, A. A., \& Strickland, A. J. (2003). Strategic Management: Concepts and Cases (12th ed.). New York: McGraw-Hill.

Wilson, A. (2003). Marketing research: An integrated approach. Harlow: Pearson Education Limited.

Yin, R. (1994). Case Study Research (2nd ed.). Thousand Oaks, CA: SAGE Publications.

Yin, R. K. (2003). Case study research; design and methods. California: Sage Publications. 